Rochester Institute of Technology

RIT Scholar Works

Articles

Faculty \& Staff Scholarship

Summer 2015

\title{
Occupy Judaism: Religion, Digital Media, and the Public Sphere
}

\author{
Ayala Fader \\ Fordham University \\ Owen Gottlieb \\ Rochester Institute of Technology
}

Follow this and additional works at: https://scholarworks.rit.edu/article

Part of the American Politics Commons, Communication Technology and New Media Commons, Critical and Cultural Studies Commons, Digital Humanities Commons, Jewish Studies Commons, New Religious Movements Commons, Politics and Social Change Commons, Practical Theology Commons, Religious Thought, Theology and Philosophy of Religion Commons, Social and Cultural Anthropology Commons, Social Influence and Political Communication Commons, Social Media Commons, Speech and Rhetorical Studies Commons, and the Theatre and Performance Studies Commons

\section{Recommended Citation}

Fader, Ayala and Owen Gottlieb. 2015. "Occupy Judaism: Religion, Digital Media, and the Public Sphere. " Anthropological Quarterly 88(3):759-794.

This Article is brought to you for free and open access by the Faculty \& Staff Scholarship at RIT Scholar Works. It has been accepted for inclusion in Articles by an authorized administrator of RIT Scholar Works. For more information, please contact ritscholarworks@rit.edu. 
Appears in:

Fader, Ayala and Owen Gottlieb. 2015. "Occupy Judaism: Religion, Digital Media, and the Public Sphere. " Anthropological Quarterly 88(3):759-794.

Author's Post-Print

Occupy Judaism: Religion, Digital Media, and the Public Sphere

Ayala Fader and Owen Gottlieb

Gottlieb: School of Interactive Games and Media

Golisano College of Computing and Information Sciences

and

Initiative in Religion, Culture, and Policy, MAGIC Center

Rochester Institute of Technology

KEYWORDS: Occupy Wall Street, digital media, religion, public sphere, Judaism, social media, social protest, political protest 


\section{ABSTRACT:}

This article provides an analysis of Occupy Judaism, an explicitly religious expression of Jewish protest, which occurred simultaneously with Occupy Wall Street, the directdemocracy movement of 2011. Occupy Judaism, like Occupy Wall Street, took place both in physical spaces of protest in New York City and digitally, through mobilizing and circulating debate. The article focuses on the words and actions of Daniel Sieradski, the public face and one of the key founders of Occupy Judaism, supplemented by the experiences of others in Occupy Judaism, Occupy Wall Street, and Occupy Faith (a Protestant clergy-led initiative). We investigate what qualified as religion in the public sphere of Occupy Wall Street, the implications of activities that blurred the lines between religious and secular in the context of public protest, and the relationship of these place-based activities to digital practice. The article emphasizes the importance of ethnographically investigating both physical protest and digital debate, which in this case created the potential for Jewish leftist religion to occupy a new space in the public sphere for a short time in 2011. Attention to the mediation of religion in the public sphere has implications for rethinking what constitutes the political, the religious, and the secular, as well as how digital practices may be implicated in debates over these terms. 


\title{
Occupy Judaism: Religion, Digital Media, and the Public Sphere
}

\author{
Ayala Fader, Fordham University \\ Owen Gottlieb, Rochester Institute of Technology
}

Occupy Wall Street (OWS), a direct-democracy movement, began in New York City's Zuccotti Park in September 2011 and was evicted by the New York City Police Department by November of that year, after having spread throughout the US and internationally. The Occupy movement's protestors critiqued growing economic and social inequities, greed, corruption, and the increasing influence of corporations on government. They attempted to remake the public sphere in response to what they identified as the crises of global capitalism and representative democracy (Juris 2012). Occupy protestors created an alternative moral community in the public square, on city streets, and in the public imaginary (Nugent 2012). This community was anti-authoritarian and anti-hierarchical, emphasizing horizontal, consensusbased decision making in general assemblies.

Digital media practices and the occupation of physical public space were both key for organizing and creating this alternative community. Indeed, recent work on direct-democracy movements, particularly Occupy Wall Street (e.g., Graeber 2011, 2013; Juris 2008, 2012, 2013; Lievrouw 2011; Postill 2013; Razsa and Kurnik 2012) and the "Arab Spring" movements in the Middle East (e.g., Beaumont 2011, Eltantawy and Wiest 2011, Sreberny and Khiabany 2010), has shown the centrality of new media to these political protests. These scholars have emphasized the importance of examining how "virtual and physical forms of protest" constitute each other (Juris 2012:260).

In this emerging body of literature, despite religion's prominent role in many recent direct-democracy movements, there has been little ethnographic attention to how groups who define themselves in religious terms have participated on the ground and through digital media 
practices. ${ }^{1}$ OWS organizers themselves were keenly aware of the important role of religion in the North American public sphere, which has never been completely secular, having long incorporated a tension between religious freedom and Christian values and rhetoric (Calhoun 2011:120). They were thus explicitly inclusive of religious iterations of political protest, for, as one organizer noted, "America is a country that believes in God, and so saying this [OWS] is a secular movement excludes 99 percent of the people.

\section{Figure 1: Occupy Kol Nidre at Brown Brothers Harriman, NYC.}

[see Anthropological Quarterly publication for image]

(C) 2011 Julie Dermansky/First Published by The Jewish Week

In this article, we analyze an explicitly religious expression of Jewish protest, which occurred both in physical spaces in or near OWS in New York City and digitally, through mobilizing and circulating debate. We suggest that this particular case can make methodological and theoretical contributions to broader discussions of the place of religion in the US public sphere today. Our analysis focuses primarily on the words and actions of Daniel Sieradski, the public face and one of the key founders of Occupy Judaism (OJ). We supplement this data with interviews with three other leaders of OJ and OWS and, as a point of comparison, one of the leaders of Occupy Faith, a clergy-led Protestant initiative situated in Zuccotti Park. ${ }^{2}$ OJ, though never a united organized movement, spread to cities around the US and even internationally, slowing down in November 2011 along with OWS (see timeline below). The Jewish fall-holiday cycle from October through December 2011 gave OJ momentum and structure, with the goal, as Sieradski posted on Facebook, to "bring Judaism to Occupy and bring Occupy to Judaism."

OJ was both a physical protest and a virtual one. Sieradski along with others used 
digital media to organize Jewish ritual performances in Zuccotti's public square. Simultaneous with the performance of these rituals, there was a great deal of debate on social media about the political meaning of OJ, much of which revolved around contested definitions of Judaism and its role in the alternative public sphere of OWS. Like much of post-war US Judaism, Sieradski and OJ defined Judaism as a religious discourse, though many Jewish practices do not resemble those of other religions, particularly not US Protestantism (Cohen and Eisen 2000, Prell 2000, Shandler 2009). ${ }^{3}$ Here, we ask how and why Sieradski narrated his choices of particular religious rituals to be an expression of Jewish political protest. We also consider the relationship of these rituals to digital practices, especially given the existence of more secular alternative forms of Jewish protest at OWS. ${ }^{4}$

We argue that Jewish ritual in the public square and debates over these rituals on digital media destabilized the discrete categories of religious and secular, creating the potential for leftist religion to occupy a new space in the public sphere. We use the term "public sphere" in a Habermasian sense to denote an imagined space of political debate (Habermas 1989, 2011), and "public square" to denote the public physical spaces in which participants protested, including Zuccotti Park, though it is technically a privately owned public space. What Sieradski called "traditional" ritual expressions of Judaism in the public square troubled secular historical temporalities, secular public space, and secular constitutional rights. However, the ritual protests in Zuccotti were only one part of the emergence of OJ. Digital media, where OJ was debated, revealed diverse Jewish political and cultural discourses that were distinct from the religious idiom that shaped the rituals in urban space. That is, on social media sites there were ongoing struggles among Jews and between Jews and other Occupy activists about the definition, responsibilities, and legitimacy of the Jewish religious left more broadly in the newly imagined public sphere of OWS.

But how should we understand the Internet in broader conversations about the public 
sphere? Papacharissi (2002) investigates whether or not the Internet might be a new kind of public sphere. While this characterization may be accurate in some contexts, our research on a direct-democracy movement suggests that, in contrast, the alternative public sphere of OWS was constituted by the dynamic feedback loop between digital media practices and physical protest in public space; as such, this requires ethnographically investigating the movement in both virtual and grounded spaces. Thus, we discuss what qualified as religion in the public sphere of Occupy, the implications for activities that blurred the religious and the secular in the context of public protest, and the relationship of these place-based activities to digital practice. We suggest that an ethnography of Jewish activism as part of OWS can teach us about the potential place of radical leftist religion in the US public sphere today which, as Calhoun notes, has been dominated by the Religious Right since the 1970s (2011:118-119). ${ }^{5}$

Attention to the mediation of religion in the public sphere has implications for rethinking what constitutes the political, the religious, and the secular, as well as how digital practices may be implicated in debates over these terms altogether. In a reformulation of his now-classic secular concept, Habermas has acknowledged that religion must be a part of the public sphere $(1989,2011)$. However, in order to share a common language, Habermas suggests, the values and ethics of religion must be "translated" into a "secular idiom" of shared "rational" terms (see Mendieta and VanAntwerpen 2011:4-5). This seems to assume that religion is easily recognizable — that we know what religion looks like, perhaps by its non-rational or transcendent discourses.

In contrast, we treat claims to religious identification, both digital and on the ground, as a point of ethnographic departure in order to make discussions of the public sphere less abstract. How, for example, is the performance of a Jewish ritual in and around Zuccotti Park different from or similar to gathering under a banner for Camp Kinderland (a secular Jewish socialist camp) alongside other OWS protestors in Zuccotti? Similarly, how does online 
debate about a ritual contrast to the physical performance of that ritual in secular space? Finally, what do these activities tell us about the ongoing constitution of the very categories of the religious and the secular in the US public sphere? An approach that integrates online and offline activities in direct-democracy movements requires that we analyze struggles to define the religious, the secular, and the political in the public sphere today.

Anthropologists who study religion and media have begun examining how the religious sensorium might contribute to the remaking of the public sphere (e.g., Fader 2013; Hirschkind 2006; Hirschkind and Larkin 2008; Meyer 2004, 2009; Meyer and Moore 2006). Others have focused on the ways religion is practiced on or with digital media (e.g., Amkraut 2011; Campbell 2012; Campbell and Golan 2011; Fader 2012, 2014; Gottlieb 2013a, 2013b, 2015; Shandler 2009; Stolow 2010; Wagner 2011). We build on these literatures to argue for an interrogation of the very claims activists make to religion and religious practice, online and on the ground, especially as they contrast to other formulations of political activism.

What follows is an analysis of the brief flourishing of OJ in the context of the OWS movement. After a discussion of our research methodology, we provide historical context in order to understand current intra-Jewish debates about religion and politics, as well as a short religious and digital 
Figure 2: Timeline of Key Events in Occupy Judaism and Occupy Wall Street in New York City. ${ }^{6}$

\begin{tabular}{|l|l|}
\hline $\begin{array}{l}\text { OCCUPY JUDAISM } \\
\text { (New York Events) }\end{array}$ & $\begin{array}{l}\text { OCCUPY WALL STREET } \\
\text { (New York Events) }\end{array}$ \\
\hline $\begin{array}{l}\text { September 17, 2011 } \\
\text { Protestors at Zuccotti Park } \\
\text { begin informally celebrating } \\
\text { Sabbath together. }\end{array}$ & $\begin{array}{l}\text { July 13, 2011 } \\
\text { Adbuster Magazine posts a call } \\
\text { to occupy Wall Street. }\end{array}$ \\
\hline $\begin{array}{l}\text { October 7, 2011 } \\
\text { Kol Nidre Yom Kippur Service } \\
\text { is organized on Facebook } \\
\text { page. }\end{array}$ & $\begin{array}{l}\text { September 17, 2011 } \\
\text { Occupation in Zuccotti Park } \\
\text { begins. }\end{array}$ \\
\cline { 2 - 2 } $\begin{array}{l}\text { October 15, 2011 } \\
\text { Sukkot (ritual booths) are } \\
\text { erected in Zuccotti Park. }\end{array}$ & $\begin{array}{l}\text { O00 protestors are arrested on } \\
\text { the Brooklyn Bridge. }\end{array}$ \\
\cline { 2 - 2 } $\begin{array}{l}\text { October 20-21, 2011 } \\
\text { Occupy Simchat Torah takes } \\
\text { place. }\end{array}$ & $\begin{array}{l}\text { October 4, 2011 } \\
\text { Protests spread nationwide. }\end{array}$ \\
\cline { 2 - 3 } $\begin{array}{l}\text { November 4, 2011 } \\
\text { The "flotilla tweet" is posted } \\
\text { and then deleted. }\end{array}$ & $\begin{array}{l}\text { Week of October 17, 2011 } \\
\text { Arrests take place across the } \\
\text { country. }\end{array}$ \\
\hline $\begin{array}{l}\text { December 22, 2011 } \\
\text { Occupy Hanukkah holds a } \\
\text { candle lighting at Zuccotti Park } \\
\text { to "remember the desecration } \\
\text { of holy space." }\end{array}$ & $\begin{array}{l}\text { Surprise raid clears Zuccotti } \\
\text { Park; campus rallies take place, } \\
\text { and Occupy moves onto } \\
\text { Harvard and the City }\end{array}$ \\
\hline $\begin{array}{l}\text { April 1, 2012 } \\
\text { Occupy Passover and Holy } \\
\text { Week are celebrated at Judson } \\
\text { Memorial Church with Arthur } \\
\text { Waskow. }\end{array}$ & $\begin{array}{l}\text { University of New York. } \\
\text { May 1, 2012 } \\
\text { New York City. }\end{array}$ \\
\hline $\begin{array}{l}\text { September 12, 2012 } \\
\text { Occupy Rosh Hashanah/Jewish } \\
\text { New Year; one-year anniversary } \\
\text { is celebrated with OWS in } \\
\text { Zuccotti Park. }\end{array}$ & $\begin{array}{l}\text { September 12, 2012 } \\
\text { One-year anniversary is } \\
\text { celebrated with OJ and Occupy } \\
\text { Faith in Zuccotti Park. }\end{array}$ \\
\hline
\end{tabular}

biography of Sieradski. Then we discuss three Jewish rituals that were performed in or near Zuccotti Park, focusing in particular on the performance of the religious rituals in secular spaces and their relationship to political activism. We contrast Sieradski's crossing of discrete boundaries between 
the religious and secular with analyses of the online organizing, debates, and circulation of images and texts that occurred simultaneously with the rituals or, in one case, after. Many of these were debates contesting the very definition of Judaism — in terms of politics, religiosity, and the secular in the US. These debates reveal both the problems of diasporic Jewish involvement in leftist direct-democracy movements, especially in regards to Israel/Palestine, and, more broadly, the interplay between physical and digital spaces in the study of religion in the public sphere (see Figure 2).

\section{Research Methodology}

The recent and relatively short life of OJ (September 2011-September 2012) shaped our research methodology. We met and began our collaboration in March 2012, after OWS and Occupy Judaism protestors had been evacuated from Zuccotti. However, back in 2011, we had separately attended the first ritual event, Occupy Kol Nidre. Fader, an anthropologist of Jews and Judaism, was curious what a Jewish expression of solidarity with OWS would be like. Gottlieb, a Reform rabbi and graduate student, came as a health insurance reform activist and colleague of many of the organizers. Our different backgrounds, interests, and loyalties echoed the ongoing intra-Jewish debates that OJ activists had to negotiate, as we discuss below.

Because we were interested in the relationship between digital media and the Jewish rituals performed at or near Zuccotti as protest, we examined and compared a range of communicative practices online (on Facebook, Twitter, and via e-mail) and offline (see Mattoni 2013). Our methodology drew on approaches from the anthropology of media (e.g., Campbell 2011, Coleman 2010, Ginsburg 1994, Ginsburg et al. 2002, Ito et al. 2009). Thus, we attended to how organizers used and talked about their digital practices in the context of the wider media ecology.

As more traditional participant observation was not a possibility for most of what we describe, we decided to focus on the key organizer of Occupy Judaism, Daniel Sieradski, two 
other participants in OJ, Pastor Michael Ellick of Occupy Faith, and Justin Wedes, a member of the OWS Media Committee, who was also tangentially involved in a Jewish arts organization and knew Sieradski. We conducted ethnographic interviews with these five individuals, while Fader conducted participant observation at two additional events co-sponsored by OJ, which occurred in April 2012 and on the one-year anniversary of Occupy in September 2012. We do not claim that the leaders we describe are representative of the range of involvement in OJ, OWS, or Occupy Faith. However, we contend that they were important motivating forces behind the movements, both digitally and on the ground, whose involvement overlapped at particular points in ways that highlight each movement's distinctiveness.

This article, then, focuses on the social relationships and histories of a few charismatic individuals (particularly Sieradski) who became the public faces of their respective movements for several months. These individuals, we believe, can serve as prisms through which to examine the complexity of religious ritual, digital media, and political protest in the public sphere of OWS.

\section{Historical Background: Jewish Religiosity and Political Protest}

To understand OJ's relationship to OWS and Occupy Faith, it is important to examine the wider historical context of post-war intra-Jewish debates in the US over the very meaning of Judaism, how it should be practiced, and its relationship to political activism. These debates continue today, albeit in a very different historical moment both for Judaism and for religion more generally in the US. Michael Staub (2004) provides excellent background for our discussion in his analysis of these debates from the 1940s through the 1970s. Staub (2004:7) shows that assumptions about the postwar Jewish commitment to liberalism, as an effort to dissociate religion from politics, glosses significant and ongoing disagreements among Jews about the relationship between religion and political activism.

Of particular relevance for our discussion, Staub recovers what he calls the "religification" 
of politics beginning in the late 1960s and 1970s, which coincided with a Jewish "renewal of religious life and communal devotion" in the US (2004:8). Thus, while there were certainly many important Jewish political activists in the 1960s and 1970s who did not use Jewish religious discourse (e.g., Abbie Hoffman and Jerry Rubin), there were also other Jews from all political persuasions who, in a break with their parents' generation, increasingly used shared Jewish religious terms and texts to bolster their claims that they were saving "authentic" Judaism for future generations (2004:14-15). For example, in the 1960s and 1970s Jewish activists from the far left, the far right, and moderates all invoked the Torah and Talmud to support their disparate political positions. They adapted religious rituals to make political statements, especially about Israel/Palestine, Civil Rights, the Vietnam War, anti-Semitism, the Holocaust, and many other issues of the day (Staub 2004:8).

OJ certainly spurred intra-communal debates among contemporary Jews over similar issues, ${ }^{7}$ however, much has changed in the US since the 1970 s, where Staub's history leaves off. Particularly relevant here has been the increasingly and, for many social scientists, unexpected political and very public activism of the Religious Right in the public sphere. Thus, we have seen predominantly evangelical Christians in the US who used supposedly secular political spaces to further their own religious agenda (Calhoun 2011:123-124). This activism occurred alongside neo-liberal developments, like growing disparities in wealth and increasing corporatization, all of which provoked the formation of OWS (Graeber 2012, Harvey 2005). As one member of OWS described, "We wanted an alternative to the Tea Party."

In this historical context, with OWS attempting to create an alternative public sphere to remake democracy, we investigate why one of the key founders of OJ, Dan Sieradski, chose Jewish religious ritual as a form of protest in the public square and used digital media to organize and legitimize his choices. There were other non-Jewish religious groups and other more secular Jewish groups who organized and participated quite differently from OJ. For example, rather than 
organize their own religious rituals, other leftist Jewish organizations, such as Jews for Social and Economic Justice (JFREJ), Jewish Voice for Peace (JVP), and Camp Kinderland, participated directly in OWS in Zuccotti as interest groups (though they sometimes also participated in OJ ritual performances). Similarly, Michael Ellick, the pastor of the progressive Judson Church who was a key organizer of Occupy Faith - the loose organization of Protestant churches, a few liberal synagogues, and some Buddhist temples — staked out a permanent physical spot in Zuccotti for conducting rotating religious services on Saturdays and Sundays.

OJ, and specifically its leader, Dan Sieradski, did not work with Ellick of Occupy Faith until the movement was winding down, nor did OJ become well-integrated into OWS, either in Zuccotti or in the horizontal digital organizing that occurred through the General Assembly (for example, by becoming a working group). ${ }^{8}$ Instead, OJ moved fluidly between spaces—-secular and religious, Jewish and non-Jewish—refusing to be relegated to one fixed spot, physical or virtual, in the broader OWS movement.

Sieradski's OJ sparked intra-communal debate among Jews, much as Jewish religious political activism had in the 1960s and 1970s over Jewish legitimacy, authenticity, and continuity, including recurring concerns with anti-Semitism and conflict over Israel/Palestine. Sieradski tried to make time and space — digital, physical, and imaginary—-for Jewish religious rituals and create texts that would provide what he called an "authentic" Jewish experience for participants, a claim we analyze below. He also drew on a religious history he hoped would not only legitimize the wider OWS movement, but would actually become key to shaping the protest.

\section{Daniel Sieradski: Public Jewish Activist, Online and Offline}

In his study of Occupy Boston, Juris (2012) suggests that the Facebook and Twitter organizing of contemporary direct-democracy movements like OWS are creating new forms of social protest. Previously, he suggested, movements drew on listservs and websites to create 
"networked" protest groups. Social media, in contrast, according to Juris (2012), draws together diverse groups and "aggregates" them in physical space. OJ was, in contrast to Occupy Boston, more ambiguous to define because Sieradski was such a complicated public figure whose own digital practice moved in and out of networking and aggregating, just as his own activities (online and offline) blurred boundaries between secular/religious and Jewish/American historical temporalities and spatialities.

Sieradski was deeply implicated in the Jewish institutional world in New York and Israel and simultaneously deeply critical of both. His religious and political biography, his dense digital networks and expertise, and his experience with Jewish non-profit organizations all uniquely positioned him to transform his informal Sabbath celebrations with friends, as protestors in the early days of Zuccotti, into a digitally mobilized series of rituals in public space. It was these rituals which defined OJ. Sieradski's rationale for organizing the first OJ event, Occupy Kol Nidre (the opening ritual for the Day of Atonement or Yom Kippur), is illustrative of his understanding of Judaism and its relationship to his own radical politics. While there were many Jews involved in OWS, he suggested to us that they were "involved as activists not as Jews...they did not choose to express their affiliation with the movement as Jews." This statement clarifies that, for Sieradski, in order to express one's political affiliations "as Jews," protestors must participate in Jewish rituals and prayer or frame political acts with religious texts. For Sieradski, then, to be an activist "as a Jew" meant drawing on religious terms, ideas, or texts and even more particularly, as we discuss later, using a notion of "traditional" religion. In fact, the focus on the religious practice, texts, and ethics of Judaism enabled Sieradski to claim that Judaism need not be circumscribed, as Occupy Faith was, to a particular space or place in the public square of OWS: Judaism might instead transcend its religious frame to guide the public sphere of protest.

In Sieradski's definition of Judaism, we can see a continuity of the "religification" of the strand of post-war Jewish activism that Staub (2004) described. Indeed, many of Sieradski's 
networks, which participated in OJ, included Jewish millennials who had grown up in the counter-cultural Havurah movement (an egalitarian religious movement from the 1960s). For them, Judaism was similarly defined by ritual, prayer, and religious text, performed simultaneously as political protest. One participant told us that he endorsed the service through his personal networks once he was convinced it would be a "good davening [prayer] experience" based on who had agreed to lead the service. This implies that the quality of the prayer (based on the service leadership) determined whether or not the political event (Occupy Kol Nidre) itself would be worthwhile.

Born in 1979, Sieradski's own experience of Judaism was most likely one factor explaining the emphasis on ritual and the holiday cycle, along with digital activity, that defined OJ. He told us that he had grown up "in and out of Orthodox Judaism" referring to himself most recently as "post-Orthodox." Sieradski had a complex relationship to Israel, as both a strong supporter of the country and a loud critic of the Israeli occupation. In the US, Sieradski was also involved in the radical protest of the war in Iraq.

Sieradski had a similarly complicated relationship with Jewish institutions. He was publicly critical of North American synagogue life and the North American Federation system (a Jewish confederation of social-service groups and educational organizations which distributes money to Jews and non-Jews), especially over their unquestioning support of Israel. He explicitly hoped to radicalize Jewish institutions, as well as involve young Jews in the growing Occupy movement. At the same time, however, he was implicated in both creating new Jewish organizations and working for Jewish non-profit organizations. For example, Sieradski founded a number of important Jewish websites and blogs oriented toward progressive, Jewish millennials, such as Jewschool, Radical Torah, and Orthodox Anarchist, among others. Nevertheless, he also worked for some well-established Jewish organizations as their digital media point person, such as the Jewish Telegraphic Agency (a Jewish news site) and Repair the World (a Jewish volunteer 
social-service agency). Sieradski was, thus, an insider to and a critic of the Jewish institutional world, as well as a public figure among Jewish professionals with legions of digital followers.

\section{Digital Organizing: Creating Religious Authority Online}

It was Sieradski's positioning as both insider to and critic of Jewish organizational life that enabled him to mobilize his contacts in OWS and in the Jewish institutional world, while undercutting the authority of both. The digital organizing of OJ events created alternative hierarchies of authority, which used but also bypassed the authority of more established Jewish leadership, particularly synagogues. This contrasts to Occupy Faith, which organized their OWS involvement through church leaders, who in turn mobilized their congregations. Further, digital practice was much less important to Occupy Faith than it was to OJ or OWS. This is most likely generational, as most of the church leaders were older and not as invested in social media.

The alternative forms of authority that digital media may support must be considered in the context of social networks outside of the virtual, making a focus on the relationship between face-to-face and digital practice critical. For example, the very inspiration for OJ occurred in the early days of OWS in Zuccotti Park, as we noted, when Sieradski and other Jewish social activist friends were "hanging out...and all this Jewish stuff started to percolate." Friend networks protesting in the politicized space of the OWS encampment decided to create an impromptu Sabbath celebration one Friday evening. Again, because Sieradski was a public figure who was well known to the Jewish newspaper, The Forward (he had worked at the Jewish Telegraph Agency, physically down the hall), a reporter came out to cover the event. Reading this story prompted Rabbi Arthur Waskow, a key figure in the religification of Jewish activism in the Civil Rights Movement of the 1960s and 1970s, to e-mail Sieradski (actually a former student of his) and suggest that Sieradski organize a Yom Kippur ritual as part of OWS. 
First, Sieradski had to get what he described as "buy in" from the OWS General Assembly. He attended these meetings along with friends and colleagues from Jews for Racial and Economic Justice, a Jewish arts group, and Havurah and Renewal circles (both egalitarian alternative forms of Judaism). ${ }^{9}$ Justin Wedes, a member of the media group for Occupy, was also a member of a Jewish arts group and knew Sieradski. He would become Sieradski's entry point for conversations between OJ and OWS. Occupy gave their permission through Wedes, suggesting OJ hold the service in the plaza of the investment bank Brown Brothers Harriman, across the street from Zuccotti. This was, in part, because the General Assembly was having its own meeting in Zuccotti then and also because, Sieradski told us, they had hopes of "expanding the Occupation" out from Zuccotti.

Sieradski's face-to-face organizing led to the formation of a digital archive with its own networks of authority. The compression of time that digital networks create allowed the ritual to be planned in a few days. First, Sieradski proposed the idea for the service on a closed Google Group that he participated in with other young Jewish professionals committed to social justice, whom he knew personally. He noted that, for him, what we call "digital authority" was based on those who were "curators of good content"- those who either "break news" or "connect lots of great people." A good curator may not be a prominent person, Sieradski noted. He followed people who were "nobodies but are really great aggregators." However, it was Sieradski's own distinction as an unusually effective aggregator that made his idea for the service spread so quickly.

As posts and shares circulated, they could be judged and evaluated, searched for, and even erased. The critical assessment of the person posting and the content of the post created a form of authority based on social networks, numbers of followers, and the ability to mobilize and make events happen on the ground. Authority in these networks was constituted by individual judgments about the legitimacy of the poster and the posted content, as well as the ability to cross over from the virtual to the emplaced. 
The choice to make OJ's first event a religious ritual mitigated the political implications of such a ritual performance. Thus, a few Jewish organizations offered access to the necessary religious objects despite their hesitancy to support Occupy politics more generally. For example, Sieradski recounted that someone from the Rabbinical Assembly (the organization for Conservative Judaism) saw his posting for the event on Facebook and wrote, "Hey dude, not that we're endorsing the politics of OWS, but if you need machzors [prayer books for Yom Kippur], we will donate them....and here's a pdf too [which people could download]." Similarly, Sieradski's mother found an Orthodox synagogue willing to loan him a Torah scroll for the ritual, on the condition that their loan remained anonymous. What emerges from these examples is that many synagogues and non-profit organizations did not want to be associated with Occupy politics, in part, according to Sieradski, because they did not want to alienate members and donors who had made their money on Wall Street. However, when Sieradski's call was framed as a request for Jewish ritual objects, individuals from at least two organizations were quick to help. Next, we turn to the unexpected possibilities for public, collective, Jewish presence expressed through rituals both in and near Zuccotti Park.

\section{Occupy Kol Nidre: Religious Ritual and Secular Public Space}

In his recounting of the Kol Nidre ritual, Sieradski invoked a very specific historical lineage for OJ. He cast protestors as the direct inheritors of prophetic Judaism (e.g., Isaiah, Hosea, Micah), which, in turn, inspired Jewish religious radicals of the 1960s and $1970 \mathrm{~s} .{ }^{10}$ Sieradski remembered waking up with the Prophet Isaiah's words, which are read on Yom Kippur, in his head. He told us:

Isaiah's pronouncements that the fast that God wants of us [Jews fast on Yom Kippur] is not merely to fast for a day, but that we should house the homeless, clothe the naked, feed the hungry, and break the bonds of oppression and wickedness. And then, I was like...well 
I'd rather be doing that than go to shul [synagogue], so let's see if anyone bites at this. Sieradski selectively invoked a particular history and definition of Jewish activism through ritual performance, which cast the organizers as contemporary prophets both for the diversity of Jews who were participants, as well as for Occupiers in Zuccotti Park.

It was the placement of the ritual in social space, rather than ritual innovations (though there were some, as we discuss below), which laid the groundwork for Sieradski's claim to be merging religion and radical politics.

\section{Figure 3: Daniel Sieradski just prior to the Kol Nidre service.}

[see Anthropological Quarterly publication for image]

\section{Photograph by David A.M. Wilensky}

For OWS, the social space of Zuccotti Park was key, both in the practice of protest and also in the imaginary of the movement as it spread. As Juris has noted in his work on Occupy Boston, the social spaces of occupation were "emotionally vibrant sites of human interaction that modeled alternative communities and generated intense feelings of solidarity" (2012:268). Occupy Kol Nidre created a space for religious affect to be displayed in a secular public space with the purpose of aligning, but not quite equating themselves with the protestors at Zuccotti.

Similarly, in recent decades, vastly different religious groups have attempted to reclaim public spaces as sites for religious expression. For example, Engelke (2012:155) shows how a Christian organization in England appealed to sensory and material culture (e.g., by hanging an angel sculpture in a mall, hosting a Bible reading in a coffee house, etc.) to create a new space for spiritual affect in the market square by refusing and confusing the very categories of public, private, and religious.

Further, OJ ritual performances, beginning with Occupy Kol Nidre, were performed in 
different public spaces — sometimes next to and sometimes in Zuccotti-without permission from the City. The focus on space allowed the worshipers/protestors to display Jewish religious activities that were not constrained to one place or purpose in the wider OWS movement. The rituals demonstrated the power of religion to trump police authority over secular laws governing private space.

The very act of gathering for the Kol Nidre service, for example, was an act of civil disobedience, as the group did not have a city permit (which takes about a month to process). In early Facebook posts, Sieradski warned people to be prepared for the possibility of arrest if they came to participate. A discourse of ritual performance as "dangerous" in terms of the secular state permeated the ritual and its retrospective evaluation. In an interview with us, Sieradski suggested, citing Rabbi Abraham Joshua Heschel, that prayer should be a "radical, subversive act."

Similarly, Ben Murane posted this statement (on the progressive blog Jewschool; see Murane 2011) the next day: "Those of us who attended [Kol Nidre] on Friday accepted the risk because our souls were starved for meaning." The police, though out in force, did not interfere with the service, highlighting that the freedom of religious expression in public space trumped the necessity for city approval via a permit. Occupy Kol Nidre, then, was framed by Sieradski and some others as an illegal, dangerous Jewish ritual performed in privately owned public space, which transformed the space and the ritual, making both political and religious.

During the service, Sieradski and his co-organizers were careful to hew as closely as possible to a gender-egalitarian, "traditional" (Hebrew) liturgy in order to both "reflect the values of Occupy, while still being as traditional possible." ${ }^{11}$ Sieradski said, "If you're going to be inclusive you have to be traditional...I wanted all the contours of an authentic Yom Kippur service." He distinguished "traditional" Judaism as more authentic than "a flim-flam, hippy service," suggesting that to be "authentic" the service had to be in Hebrew and contain the "full" liturgy. In fact, the service appears to have drawn consciously or unconsciously from a 
number of traditions, including Reform, Conservative, Orthodox, Renewal, Reconstructionist, and Havurah Judaism. Religious ritual was not radicalized per se. Instead, the radical move was to place "traditional" ritual in a space of protest, next to OWS.

Nevertheless, there were enough ritually distinctive features that aligned embodied ritual practice in space with OWS discursive forms and politics. The protestors sat on the pavement in a circle around the giant red-cube sculpture, many wrapped in traditional white prayer shawls and white yarmulkes, rising and sitting, swaying, chanting, and singing. The human microphone - the OWS technique whereby the community echoed back to whomever was making a statement—had been employed in Zuccotti because protestors had been prohibited from using electronic amplification. At the Kol Nidre service, the human microphone took on new significance, both political and religious. The call and response between prayer leader and community is a standard part of Jewish prayer. Sieradski specifically asked participants to turn off any electronic devices to accommodate Jewish religious law. That night, the human microphone functioned both as a prayer amplifier and as political signifier of solidarity with Occupy. Other innovations occurred with the inclusion of a prayer for Palestinians during the confessional (vidui), and then, when members of the group were invited to confess their own personal sins out loud, participants raised their hands, were called on by the leaders, stood up, and confessed sins that were predominantly about issues of social injustice. These ritual practices mirrored the horizontal, non-hierarchical, and emotional meetings of OWS.

Along with these symbolic ritual innovations, Sieradski's Occupy Kol Nidre used a religious idiom to express solidarity with OWS by enacting the ritual beyond the walls of a religious institution, in public space, and near Zuccotti Park. Occupy Kol Nidre may have interpellated participants who were already observant Jews and politically progressive into the Occupy space of protest, although participants did not all necessarily ascribe to this religious iteration of Judaism; indeed, a group of Jewish journalists told us that they sat in the back and made 
Jewish jokes during the service. ${ }^{12}$ Nevertheless, during that evening Sieradski and OJ became the public face of Jewish activism at Occupy. The next day, Ben Murane posted on a blog, Jewschool (see Murane 2011):

We gathered at Wall Street because prayers without politics are flaccid...we had become bored, complacent, lazy...We came to atone not just for our society's financial misdeeds, but for sinning through unchallenging prayer.

Murane conflated the injustice of the economic system with uninspired, insincere prayer. In this analogy, religious practice and political activism inform and depend upon each other for meaning. The inferiority of intention in prayer and the public-ness of political protest together created what Murane and Sieradski defined as "authentic Judaism."

\section{Circulation Across Religious and Secular Publics}

Larkin and Hirschkind suggest attending to the circulation of forms "through which religious publics constitute themselves and their members, often in relation to or in opposition to competing forms of identity" (2008:5). The digital circulation of text and images after Occupy Kol Nidre revealed not a "religious public," but instead a Jewish public engaged in debating the legitimacy of Jewish religiosity and its expression in the public sphere of OWS. Digital media provided the forums for these competing interpretations of the Kol Nidre ritual in the Jewish press and among activists themselves.

Early on, the virtual space included op-ed pages where conservative journalists like David Brooks, and neo-conservatives Mathew Ackerman and Jonathan Neumann, critiqued OJ for "twisting tradition for political aims" (Ackerman 2011). Ackerman, a blogger for the politically conservative magazine, Commentary, wrote:

The turnout the event generated as well as the discussion it has so far provoked, are deeply troubling trends that all who care about the Jewish future would do well to take 
seriously...the organizers' attempts to combine Judaism and today's fashionable politics are simply incoherent.

On the opposite end of the political spectrum, commenter Lew Daly endorsed the ritual in the progressive Jewish journal Tikkun, saying, "[Kol Nidre] was an act of public worship, worship as ritual and worship as witness." These were two opposing ideas of how to be Jewish, with Ackerman claiming that combining Jewish ritual with contemporary politics was "incoherent," and Daly claiming that performing ritual in a public space turned the individualized act of prayer, positively, into political protest. Despite their different conclusions, both commentators were part of ongoing debates over the relationship between religion and politics and the place of communal ritual in the public sphere.

Digital forums provided a platform for Sieradski and others in OJ to remediate, remix, and repurpose images and texts, in order to legitimate Jewish ritual participation as a form of protest for other Jews. For example, Sieradski quickly posted an excerpt of Ackerman's comment on Facebook ("Occupy Judaism is a deeply troubling trend...") with the ironic comment, "Thanks guys!" The quote from Ackerman soon became part of their masthead for the OJ Facebook page. It was reproduced many times, as Commentary has long been notorious among leftist Jews for its conservatism.

Intra-Jewish debates, however, did not only occur on Jewish virtual networks; they crossed over, especially through small media, to bridge online discussion with embodied actions in the physical space of Zuccotti. This suggests that the alternative public sphere of the Occupy movement was constituted by the interplay between online and offline activities, with small media most explicitly linking the two. In this argument, we differ from Hoover and Echaibai's (2012) suggestion that small digital media, such as tweeting from a smartphone, creates a "third space" by joining virtual and embodied publics. While there are forms of circulation that are exclusively online or exclusively offline, the alternative public sphere of Occupy and OJ was premised on 
the ongoing interaction between offline and online practices.

For example, in Jewish and mainstream presses, as well as on the blogosphere, a number of Jews debated whether OWS, as a leftist movement, was anti-Semitic. To debunk rumors of antiSemitism, Sieradski and some others who were spending a lot of time at Zuccotti used tweets, circulated photos taken on cellphones, posted personal testimonials (e.g., "I was there and the same crazy guy was there each week"), and extended conversations on closed digital networks. One activist, Rachel Goldstein (a pseudonym) compared her tweeting from Zuccotti and OJ rituals to the work of a magid (an eastern European itinerant storyteller). Like Sieradski, she framed her current activism as a continuation of a heroic Jewish history. An artist in the Jewish world (meaning that a majority her Twitter followers were Jewish; she estimated 70 percent), she told us, "If I don't tweet this stuff, the Jewish community won't know about it." For example, she tweeted on October 11,2011:

Claims of anti-Semitism at \#OccupyKStreet (DC) are false. Don't succumb to conspiracy.

Fear-based propaganda is false.

These digital artifacts, generated from witnessed events in Zuccotti (and in this case Washington, DC), circulated online and were used to reassure observers and potential activists that OWS was not anti-Semitic.

The circulation of images to represent OWS and OJ, in contrast to Occupy Faith, similarly crossed both the digital realm and social spaces like New York City streets, where intra-Jewish debates took up the wider issue of how to visually represent Jewish religion and protest in the alternative public sphere of OWS. For example, the Charging Bull statue that sits on Wall Street, originally a piece of guerilla art, had become a symbol of Wall Street power. Adbustsers digitally altered that image by adding a ballerina on top of the bull and riot police in the background; it then circulated online and offline as the symbol of OWS.

In contrast, Occupy Faith's remediation of the Wall Street bull remained offline, in material 
form, thus carving out a circumscribed physical place, almost like an open-air Protestant church, for religious ritual and biblical history in the public square of protest at Zuccotti. In the second week of Occupy, a member of Catholic United crafted a golden bull out of papier-mâché and brought it to Pastor Michael Ellick and the congregation of Judson. The congregation, Ellick told us, embraced the image of "a false idol" and walked it down from Judson Memorial Church with other congregations to Zuccotti after conducting a service with it. Ellick told us, "We took the Wall Street bull and recast it as the golden calf. We juxtaposed these two symbols." He said, "It worked. People got it. They saw it down the street, they saw it and they realized that these two symbols meant something when put together..." Thus, Occupy Faith physically remediated the meaning of the Wall Street bull, which had already been remediated by OWS, by providing a biblical lineage for the alternative public sphere. At that time, Occupy Faith clergy claimed a fixed physical space for themselves within Zuccotti Park, where they held weekly interfaith services. Even in OWS's alternative public square, the public religious expression of Occupy Faith mirrored the more traditional, fixed place of liberal Protestantism in the US.

Sieradski's OJ, we suggest, was different. A week or so after the Kol Nidre ritual, Sieradski created a digital image for Facebook in which he placed the iconic image of a Jewish fiddler on the Wall Street bull (see Figure 4). The fiddler image came from Sholem Aleichem's original play (Tevye the Milkman), first performed in 1894, though it is much better known from the Hollywood blockbuster, Fiddler on the Roof (1971). This image of the fiddler on the bull was also printed on more traditional protest objects like buttons, flyers, and stickers. Sieradski told us that he used this image because it was so recognizable. 
Figure 4: Sieradski's alteration of the AdBusters poster to feature Tevye the Fiddler. [see Anthropological Quarterly publication for image]

\section{Image by Daniel Sieradski}

His choice, however, deserves greater analysis, for the fiddler is not simply a nostalgic Jewish figure of the eastern European shtetl (small town). Instead, journalist Alissa Solomon (2013) shows how Sholem Aleichem's story, which went from a play for the Yiddish stage, to a leftist theater production, and then onto Broadway and Hollywood, had an unexpectedly universal appeal as a secular symbol of tradition. Specifically, she notes that Fiddler spoke to shared anxieties of the US post-war period, including the unraveling of tradition, generational tensions, and assimilation. Given this history, Sieradski's choice of the fiddler on the bull is complex, recouping a popular secular Jewish figure for the purposes of a politically radical religious Jewish movement. Though Sieradski chose the image for practical reasons of recognizability, his choice may also reflect his hope that Jewish religiosity would resonate within the OWS movement. It may simultaneously hint at the limitations of a secular Judaism that is cultural rather than "traditionally" religious. The ritual we discuss next provides a different example of Jewish religiosity in the public square. The celebration of the Jewish holiday of Sukkot became, for a short time, central to OWS's growth.

\section{Occupy Sukkot and Simchat Torah: Jewish Ritual in the Public Square}

Charles Taylor (2007:185) describes Habermas's notion of the public sphere as a shared space in which members meet through a "variety of media" to discuss matters of common interest and to form a "common mind." Habermas (2011), moving away from his original description of the public sphere as completely secular, now suggests that religious actors must 
translate their ideas for secular interlocutors in order to participate in the public sphere. However, two rituals that were performed by OJ in Zuccotti Park soon after Yom Kippur departed from Habermas's proposal. In Occupy Sukkot and Occupy Simchat Torah, Jewish rituals — including material objects and historical narratives — became religious resources available to the wider Occupy movement in Zuccotti, ultimately, changing the course of the movement. Jewish religious ritual for a time permeated Zuccotti Park and became — through invocations of religious freedom - the means for getting around secular police bans on erecting permanent structures in the privately owned public space. Police reluctance to obstruct the right to religious freedom — to appear intolerant of public religious expression — created a space for an expanded form of political action.

Sieradski described the events of one evening when a "guerilla sukkah-building action" changed the course of OWS. The traditional sukkah is a temporary dwelling, often a hut-like structure built to commemorate the harvest holiday of Sukkot. Jews are obligated to invite guests into the sukkah to celebrate and share meals, and to sleep in the sukkah (which has a partially open roof) during the eight days of the holiday.

Since Occupiers had taken over Zuccotti, police had not permitted structures to be erected, and the police routinely took down tents and destroyed them. Sieradski, however, decided to build a sukkah. He brought legal representation to protect his civil right to worship publicly, as well as witnesses (the press) and a camera crew. This was especially significant, as it followed on the heels of the use of pepper spray during an OWS demonstration in October. Perhaps, Sieradski knew that images of the police interfering with a religious ritual — an image of religious intolerance — would be troubling to Jews and non-Jews alike.

The police were ultimately unwilling to be seen publicly interfering in the religious ritual. Sieradski explained to us:

The cops come over while we're building it and they're like, "What's this commotion over 
here? What are you building?" And somebody goes, "Oh, it's a sukkah, it's basically a tabernacle, a temporary structure the Jews live in during the holiday of Sukkot, The Festival of Booths." They go, "Oh, it's a religious thing? We're not fucking with that." And then they back off.

Despite the sukkah being illegally erected in a politicized physical space of protest where structures were explicitly prohibited, its religious significance made police reluctant to tear them down, perhaps because their action would have been framed as religious intolerance, specifically antiSemitism. Sieradski then suggested to the other protestors in Zuccotti who asked about the sukkah that they might appropriate it if they were "Jewish or they identified as a Jewish person," and build a structure for themselves. Sieradski recounted that he told other protestors in the park: Cops come up to you, say, "Listen, I'm a Jew, I'm celebrating Sukkot. We're obligated to live in temporary shelters and to invite guests to stay with us in our shelters." You know, like, try it. See how it goes.

One person tried it, Sieradski told us, and the police, in fact, took it down. Then another protestor put up a tent that was also taken down by the police. Then later that night, at midnight, when it started to rain, the religious symbol of the sukkah was extended to all in Zuccotti. Sieradski told us he heard the human microphone of OWS:

"Mic check!" "Mic check!" "Tonight." "Tonight." "We're all Jews." "We're all Jews." "Build yourself a sukkah." "Build yourself a sukkah." The religious structure of the sukkah was transformed into a tool of political protest for all of the Occupiers. That night, a medical tent went up and other tents followed. According to Sieradski, OWS activists credited OJ in the media for creating the opportunity for the tent city to be erected. As he said, "We set the precedent and then everything else happened." Shortly thereafter, Occupy Sukkot sukkah building spread to 15 cities around the world, and the tents remained until the eviction in November. 
Thus, it was a religious act that created the Zuccotti encampment. In fact, the religious idiom accomplished what OWS could not: it protected protestors from the secular police who were attempting to limit building structures and hence permanent occupation. The sukkah Sieradski erected was a religious symbol and performance, extended for the "common good" of OWS in Zuccotti, which the "secular" OWS protestors translated. The democratic right to religious worship enacted in a secular public space created new possibilities for expanding the presence of OWS. This example highlights that there is a protected space, physical and imagined, for religious ritual in the public sphere. There is also a potential for religious rituals to be interpreted in secular political terms. Perhaps, this is a legacy of the Religious Right's demands since the 1970s for greater public participation. Attempts to curtail public religious ritual by city or state authorities may now be interpreted as forms of religious intolerance.

The brief centrality of Sieradski and OJ to the strategizing of OWS also created a discursive space for Sieradski and some others to claim a religious temporality for the wider Occupy movement. The OWS movement claimed to be creating a "new" kind of public sphere through a break from the past (Nugent 2012). In contrast, Sieradski and a few other leaders of OJ aimed to anchor this new kind of community in a religious past, thus legitimating both OWS and Jewish religiosity expressed as political protest. For example, Sieradski described the Occupy Simchat Torah ritual, which celebrates God giving the Torah to the Jews. Led by influential Jewish public figure, now a rabbinical student, Amichai Lau-Lavie, ${ }^{13}$ everyone stood in a circle and unscrolled the Torah. Sieradski remembered participants, including Muslims and Christians, chanting, "This [the Torah] is the document of justice and this document espouses values embedded in this movement [OWS]." Though OWS might claim a temporality of rupture, Sieradski and Lau-Lavie both suggested that Jewish religious texts resonated with the movement's themes, adding a religiously historical perspective to Occupy.

While Sieradski's OJ was experimenting with religious and secular boundaries, spaces, 
and temporalities, other Jews were trying to reinforce them. One of Sieradski's explicit goals with the formation of $\mathrm{OJ}$ was to critique Jewish institutional life and experiment with Jewish religious expressions outside of these institutions. The discourse of danger that Sieradski and others articulated when they performed rituals without a city permit was also used to express the potential risks of their activism, since many of the protestors relied on funding from these same Jewish institutions for their employment. For example, Sieradski said that he was told by one of his employers that if he continued to lead OJ, he would have to resign from his job. Further, he lost a grant from a philanthropic organization supported by young hedge funders, which he directly linked to his Occupy activities. Similarly, Lau-Lavie told us there were economic consequences for his Jewish arts organization after he led Occupy Simchat Torah; some members pulled their money from the organization, explicitly citing Lau-Lavie's activism. Rachel Goldstein also told us that she worried that she was "destroying her career as a Jewish artist" by her participation in the rituals, since she relied on synagogues, Jewish camps, and other Jewish institutions for her livelihood. Also, though difficult to verify, Sieradski told us that he had seen a memo put out by the Jewish Federation (a Jewish community fundraising and philanthropic body) that forbade any professional with the Federation to be involved with Occupy activities. The Federation publicly denied that such a memo went out, and no hard evidence was produced to support the claim (Jewish Week 2011). The circulation of these kinds of rumors, however, speaks to a contradiction rooted in generational, political, and class differences among US Jews: many of the Jewish non-profits are funded by Jewish philanthropists, who are are themselves part of the 1 percent. For some OJ protestors, the possibility of losing philanthropic funding may have highlighted their own reliance on Jewish charitable giving, which was at odds with the broader critiques of economic inequality made by OWS.

Anxieties over job security had been an ongoing issue for Sieradski and other Jewish professionals involved in OJ from the beginning. However, after the forced evacuation from 
Zuccotti Park in November 2011, there were a series of online conflicts over the Palestinian cause, which Sieradski argued led to the downturn of OJ. The conflicts, which occurred exclusively over social media, speak to two issues we turn to in the next section: the significance of leadership and bureaucracy, even in direct-democracy movements, and the centrality of physical space.

\section{Israel/Palestine on Social Media}

November 2011 was a turning point for both OJ and OWS. As it grew colder and the evictions by then-Mayor Bloomberg grew increasingly probable, both movements faced questions about the future. Without the physical public space of protest, both struggled with how to continue to build an alternative public sphere, which had emerged and relied both on protest in physical space and debate within growing digital networks.

For OWS activists, the immanent threat that the physical encampments in Zuccotti (and other sites) might be shut down contrasted with the potential for continued growth that online social networks offered. Sieradski and OJ had another dilemma. OJ allied itself with progressive Jewish diasporic politics in the shared space of Zuccotti. At the same time, there was a growing concern for some that OWS's platform was increasingly critical of Israel and pro-Palestinian. With the public square of protest shutting down, debate over Israel/Palestine on social media grew increasingly divisive, as did competing struggles to frame Jews (both American and Israeli) as either a colonizing nation or a religious interest group.

To contextualize, it is important to recognize that debate about Israel has been at the heart of the most difficult rifts in contemporary American Jewry, with some younger Jews distancing themselves from Israel altogether (Cohen and Kelman 2010, Kelner 2010, Sasson 2013). Until recently, the Israel lobbying group (AIPAC) dominated discussions of Israeli policies, though some more progressive and critical voices have emerged in the last decade (e.g., J Street). However, while there may now be more debate among Jews about Israel/Palestine, for many of 
the young progressive Jewish professionals (i.e., those involved in OJ), the Boycott, Divestment, and Sanctions Movement (BDS) was, as Ben Murane explained, a "bright line in the sand" that many would not cross, either for ideological or practical reasons like job security. ${ }^{14}$ This has created potential conflicts for some politically progressive Jews who participated in leftist social movements, which include support for BDS as part of their platform. ${ }^{15}$

In the initial months of OWS there had been very little conflict over Israel/ Palestine. As we noted above, Sieradski had primarily been concerned with debunking charges that OWS was anti-Semitic. Sieradski told us that he had spent the last ten years in the Jewish community trying to change attitudes about the Israeli Occupation, especially by opening space for dissenting Jewish voices. Despite these efforts, he attributed the withdrawal of support by some Jews for OJ to a moment he called the "flotilla tweet."

This was a tweet in solidarity with the flotilla headed to Gaza that came from OWS's Facebook page: "We support and would like to express \#solidarity to \#FreedomWaves \#Palestine \#OWS." The vituperative Twitterstorm (a flame-war of tweets) that followed from that tweet and other Facebook postings about Israel/Palestine created a digital archive (D. Taylor 2010) that, without the ballast of the physically occupied space of Zuccotti, escalated quickly.

Archives — digital and physical—always involve choices, exclusions, and inclusions that are essentially struggles over whose narrative or voice will be preserved (D. Taylor 2003). The contours of OWS's and OJ's public-facing digital archives (Twitter and Facebook) were similar, although acts of erasure were both rapid and, for a short while, visible. Sieradski told us that the flotilla tweet was tweeted out by a member of the OWS media team, but without consensus. Many on the Gaza flotilla saw the tweet (Lorber 2011), as did others who followed OWS.

Upon seeing the tweet, Sieradski described how he e-mailed his contact on the Occupy media team, Justin Wedes, to ask if the General Assembly had approved the tweet (i.e., through consensus). Sieradski appealed to the bureaucratic process of consensus building, a defining 
feature of the alternative community of OWS, by questioning the chain of endorsement and collective approval of the tweet. After 15 minutes, Wedes removed the flotilla tweet because, as he told us, "Though nobody ever thought that every tweet should get consensus...there was this idea that you could be in solidarity with these causes...but I saw that tweet and it was pushing beyond what I thought solidarity meant." Wedes was an insider to both OWS and OJ. In this case, he chose to foreground the need for consensus that important decisions required as part of OWS's horizontal governance structure by removing the tweet. Nevertheless, his action conflicted with what he called "the idea that you could be in solidarity with these causes"—in other words, the idea that working groups had the right to express their own political alliances and tweet them out through Occupy.

After the tweet was deleted, there was a Twitterstorm, which was a much more public expression of outrage at what was seen as a hierarchical move. Sieradski recounted, "...the tweet disappears. And you just see Twitter filling with people going, 'What the fuck? Why did Occupy just delete that? No!"' Sieradski tweeted that the General Assembly had not approved the position. He attempted to defend the tweet's deletion by appealing to the morality of the communicative norms of consensus that were definitive of Occupy.

However, his strategy did not work. Sieradski became the target of tweets over the next three days from the Palestinian Solidarity Committee (a working group) of OWS. The tweets, which Sieradski characterized as "screaming," included direct attacks, such as "you dirty evil Zionist... fascist...Palestine genocider...Anti-Arab piece of shit...you fucking hate Palestinians." Sieradski told us that for him this exchange showed how central "anti-Zionists" were to the OWS movement. He suggested that after these tweets, "the Jews" stepped back and said "fuck this, dude." ${ }^{16}$ It is important to qualify, however, that "the Jews" Sieradski referred to were those in his social and digital networks who happened to see or read about the tweet; there were other Jews whose political stances were allied staunchly with the Palestinian Solidarity 
Committee. For example, Sieradski described complaining to representatives from Jewish Voice for Peace (JVP, one of the few Jewish groups actively supporting BDS). He said, "You're going to alienate the Jews." The representatives responded, "You're alienating the Muslims." JVP implied that Jews and Muslims were interest groups in the broader Occupy movement; this position contrasts with that held by Sieradski, Lau-Lavie, and some others, who expressed hope that Jewish history, texts, and rituals might offer something unique to OWS.

The tweet, its erasure, and the Twitter storm were all part of the struggle over how to position Jews, Israelis, and Palestinians in OWS's public sphere. Sieradski attempted to defuse a political claim (the tweet) by following protocol and appealing to Occupy's rules of communication - an appeal to process. However, he was unable to contain the tweets, which framed Jews (and Sieradski in particular) not as a diasporic religious community and not as North American citizens, but instead as a group whose allegiance to Israel and Zionism precluded their participation in leftist politics.

Finally, in February 2012, when the directions of Occupy and OJ were unclear, there was another controversy over Israel: Occupy Oakland voted to support BDS. This further distanced many of those from the Occupy movement who had been involved in OJ. On OJ's Facebook page, reports of this decision elicited numerous concerned comments. Sieradski posted that Occupy Oakland was acting independently of other Occupy groups and did not represent Occupy's positions on Israel more generally.

These political conflicts, fought over social media, emphasize the importance of examining the relationship between virtual and physical spaces of protest. Jewish religious rituals were the more publicly visible aspect of OJ. But they must also be analyzed in the context of online practices, which were not explicitly religious. Considering both the virtual and physical spaces of religious protest allows for more nuanced understandings of what constitutes religion in the public sphere at particular times and places. 


\section{Conclusions}

After the evictions of Zuccotti, OJ became less active. Activities that did occur were less distinctive - more integrated into OWS or Occupy Faith. As public activism dissipated, there was less digital practice overall as well, suggesting that digital organizing and physical spaces for protest construct each other as meaningful. ${ }^{17}$ The celebration of Simchat Torah in Brooklyn a year later (in October 2012) captures some of the shifts that took place as OJ waned. A number of synagogues and Jewish communities in Brooklyn (including a new prayer community that some of the OJ activists helped to found after the evictions) coordinated and gathered at Grand Army Plaza. Though public celebrations of Simchat Torah on New York City streets are common, especially on Manhattan's Upper West Side, liberal Brooklyn Jews had not used Grand Army Plaza in such a way in recent memory. The 2012 celebration, though reminiscent of the previous year's illegal occupation of public outdoor space at Occupy, was distinctive. This time, the organizers had a city permit to hold services and to dance outside. The human microphone was used again, but this time call-and-response was for liturgy and organization, not for political protest. There was no mention of OJ or OWS. Here was a very different kind of religion in the public sphere: a legal, institutional (including synagogue sponsors), public display of prayer in the public square, but in apolitical terms, and without the virtual spaces for contesting voices or definitions. As one of the organizers, Russ Agdern, who had been involved in OJ, remarked to us:

The Occupy Simchat Torah was definitely an inspiration in all of our minds, both that it could be done beyond the Upper West Side [of Manhattan], and that it could be done outside and show how the human mic could be useful. The one thing we haven't quite done yet is incorporate the theme of urgently needed justice and structural change that was such a part of all the Occupy Judaism events, in a meaningful way, something I hope we do in the future. 
Calhoun (2011) notes the importance of historicizing and specifying how the categories of religious and secular have been constituted (see also Asad 1993, 2003). The case of OJ contributes to this cause, emphasizing the importance of attending to religion's multiple and shifting forms. The complexity of religious forms is especially evident in the intersections of religion in secular and politicized spaces, which are constituted by dynamic interactions among the virtual, the physical, and the imagined.

Diasporic Judaism offers a particularly rich example for investigation because it does not fit easily into North American categories of religion (Fader 2009), though many have recently attempted to place it in those categories. Indeed, the short life of OJ, led in large part by the charismatic Sieradski, used digital and physical spaces and temporalities to create new possibilities for Judaism to participate in Occupy's public sphere. To only examine the rituals at or near Zuccotti, which themselves transversed secular and religious spaces, temporalities, and legalistic frameworks, would be to miss the online discussions - the "rational" political Habermasian debate among Jews and between Jews and other Occupiers. We have suggested that the feedback loop between the digital and the emplaced complicates any attempt at discrete categorization of the religious, the political, and other forms of identification.

Finally, our discussion of Sieradski's OJ points to the importance of problematizing manifestations of religion in the public sphere. Social scientists have long acknowledged that the model of privatized religion discrete from political life has little resonance today for many nonProtestant groups (if it ever had such resonance). Religious movements of all kinds are inextricably bound up with political movements, ones which now depend on digital media for mobilizing, broadcasting, and debating. In order to understand activists' identifications - be they secular, religious, or more ambiguous — we need ethnographic approaches to the religious, the secular, and the political which can account for the ways that both digital and emplaced practices together constitute today's public sphere. 


\section{Acknowledgments:}

We would like to thank those involved in Occupy Judaism, Occupy Faith, and Occupy Wall Street for sharing their thoughts and experiences with us: Daniel Sieradski, Ben Murane, Justin Wedes, Michael Ellick, Amichai Lau-Lavie, and Russ Agdern. We are also both very grateful to Faye Ginsburg and Angela Zito (at the Center for Media and Religion and Department of Anthropology, New York University), who invited us to first present at the conference, "Religion in the Digital Age: Media, Performance and "Spectacular Activism." We thank them for their guidance throughout the writing of this article. For reading drafts at various stages, we thank Marcy Brink-Danan, Jeffrey Shandler, Orit Avishai, and Lotti Silber. Fader would like to acknowledge the Memorial Foundation for Jewish Culture and Fordham University's Faculty Fellowship Program, both of which supported this research and writing. Gottlieb would like to acknowledge the Program in Education and Jewish Studies and the Program in Educational Communication and Technology, both at New York University's Steinhardt School, as well as the Jim Joseph Foundation Fellowship, which supported his Ph.D. studies. Finally, we both thank Richard Grinker, the editorial staff at Anthropological Quarterly, and three anonymous reviewers for their excellent feedback and suggestions.

\section{Endnotes:}

${ }^{1}$ Exceptions are those who have discussed the role that religious piety played in motivating the "Arab Spring," emphasizing that democracy does not require secularization (e.g., Ardic 2012, Benhabib 2011).

${ }^{2}$ With their permission, we have used public figures' real names. For those who did not want to be named, we have used pseudonyms and noted so in the text. Further, we decided to keep Jewish organizations anonymous, since several participants expressed concern that their activism had 
led to the loss of grants or other funding opportunities.

${ }^{3}$ Thanks to one of our anonymous reviewers for this phrasing.

${ }^{4}$ This contrasts with scholarship examining the religious motivations for protest movements, such as the "mosque to square" narrative (Hoffman and Jamal 2013).

${ }^{5}$ We use the word "radical" to describe the OJ activists and organizers. This best applies to the founder and most involved member, Dan Sieradski. Other activists who were involved in organizing OJ came from a wider political spectrum, although most were involved in either secular or Jewish social justice work. Nevertheless, we use the term radical in order to contrast more mainstream liberal Judaism with the Judaism of those in OJ.

${ }^{6}$ For more on the timing of these events, see http://topics.nytimes.com/top/reference/timestopics/ organizations/o/occupy_wall_street/index.html?offset=0\&s=newest (on OWS; accessed on May 25, 2015) and https://www.facebook.com/occupyjudaism (on OJ; accessed on May 25, 2015). ${ }^{7}$ In the 1980 s, for example, the ritualization of the Free Soviet Jewry movement similarly used Jewish ritual to mediate religion and politics (Kelner 2008).

${ }^{8}$ The General Assembly (GA) was the decision-making body of the OWS movement, which was open to all and used consensus as a way to actualize direct participatory democracy (Schneider 2011). Working groups, which focused on specific interests, met before GA meetings, and often one person represented the working group in these contexts.

${ }^{9}$ The Havurah Movement emerged out of the counter-cultural Jewish scene of the 1960s and 1970s. Havurot (plural) are usually volunteer-led as opposed to clergy-centric. While rabbis may be members of Havurot, they are not inherently placed in leadership roles by dint of their status as clergy. For an ethnography on a Havurah, see Prell (1989); for a history of the relationship between Havurah and political protest in the 1960s, see Staub (2004). Magid (2006) describes Renewal Judaism as a post-Holocaust spiritual phenomenon, which seeks to shift paradigms of 
contemporary Judaism (see also Weissler 2006). Renewal is non-denominational, professes egalitarianism and feminism, and is pro-LGBTQ. Renewal practice often draws on Hasidic emotionalism, the study of Jewish mysticism, ritual innovation, and is concerned with social justice and environmentalism. Rabbi Arthur Waskow is a Renewal rabbi. For more on these topics, see https://www.aleph.org/faq.ht (accessed on June 1, 2014).

${ }^{10} \mathrm{OJ}$ activists, Havurah Movement Jews, and Jews involved in social-justice activism often refer to "Prophetic Judaism." This is a reference not only to the Biblical prophets who preached about social justice, but also the theology-put-into-activism of Rabbi Abraham Joshua Heschel. Heschel, a theologian and civil rights activist, claimed he "prayed with his legs" during civil rights marches. Heschel himself was a scholar of the Biblical prophets; his dissertation was on the prophets and later became his book, The Prophets (1962).

11"Traditional" is always a fraught term in Judaism because different communities hold different traditions and because community tradition (referred to as minhag hamakom, tradition of the place) holds weight. In this article, "traditional" refers to what some of those in OJ described as "trad-egal" (traditional egalitarian). Trad-egal refers to a style in which standard Hebrew prayer rubrics, or blocks, are used and women and men have equal roles as prayer leaders and participants. Trad-egal appears to have come out of the Havurah movement and related groups including the independent minyanim scene (small prayer groups), prayer groups of Americans visiting Jerusalem on rabbinical study abroad years, and is in part influenced by Renewal Judaism retreats.

${ }^{12}$ Gottlieb suggests that joke telling during a service is part of Jewish religiosity. Fader does not agree that we can attribute religious meaning to this.

${ }^{13}$ Amichai Lau-Lavie is a contemporary public figure, who has been creating public alternative Jewish religious performance using biblical texts for years.

${ }^{14}$ The Spring 2012 conference on "Jews and the Left" at the Center for Jewish History addressed 
this issue.

${ }^{15}$ There were other millennial Jews, not directly involved in OJ, who made critiques of Zionism in physical space. For example, the short-lived Occupy Birthright had no religious content at all, but instead explicitly made a parallel between the 1 percent, the OWS movement, and the occupation of Palestine. Birthright is an organization co-founded by Michael Steinhardt and Charles Bronfman, with funding from Sheldon Adelson, among others. Through Birthright, every North American Jewish teenager is offered a free trip to Israel. A group of Birthright alumni "occupied" an event on November 10, 2011, hosted by the Birthright Alumni Association, which featured prominent Wall Street CEOs. Once there, the occupiers used the mic check strategy to read texts protesting Birthright "propaganda" and the occupation of Palestine, as writer Keira Feldman described in 2011 (accessed from http://wagingnonviolence.org/2011/11/consider-birth-right-israel-occupied/ on May 31, 2015). Sieradski was not involved in this event.

${ }^{16} \mathrm{We}$ acknowledge that there may have been other factors. For example, Murane told us that, as it grew colder and the winter weather brought sleet and snow, many of the Jewish activists wanted to observe Shabbat at home and with friends, rather than at Zuccotti Park.

${ }^{17}$ When the Zuccotti encampment was broken up, Ellick and some others of Occupy Faith tried to negotiate with Trinity Church to take in the Occupiers, since Trinity had lots of space and had initially expressed support. Ultimately, Trinity refused. Sieradski also noted that not one synagogue opened their doors to Occupiers.

\section{References:}

Ackerman, Matthew. 2011. "A Sad Mix of Judaism and Radical Politics at 'Occupy Wall Street."' Commentary, October 10. Accessed from https://www.commentarymagazine.com/2011/10/10/juda-ism-and-radical-politics- 
occupy-wall-street/on May 25, 2015.

Amkraut, Brian. 2011. "Technology: The Digital Revolution That Is Shaping 21st-century Jewish Education—A Fleeting Snapshot from the First Decade." In Helena Miller, Lisa Grant, and Alex Pomson, eds. International Handbook of Jewish Education, 597-614. Dordrecht: Springer Netherlands.

Ardic, Nurullah. 2012. "Understanding the Arab Spring: Justice, Dignity, Religion and International Politics." Afro Eurasian Studies 1(1):8-52.

Asad, Talal. 1993. Genealogies of Religion. Baltimore: Johns Hopkins University Press. . 2003. Formations of the Secular: Christianity, Islam, Modernity. Stanford: Stanford University Press.

Beaumont, Peter. 2011. "The Truth about Twitter, Facebook, and the Uprisings in the Arab World." The Guardian, February 24. Accessed from http://www.guardian.co.uk/world/2011/feb/25/twitter-face-book-uprisings-arab-libya on Feb 25, 2011.

Benhabib, Seyla. 2011. "The Arab Spring: Religion, Revolution, and the Public Square." Public Sphere Forum, Social Science Research Council. Accessed from http://publicsphere.ssrc.org/benhabib-the-arab-spring-religion-revolution-and-thepublic-square/ on May 25, 2015.

Calhoun, Craig. 2011. "Afterword: Religion's Many Powers." In Eduardo Mendieta and Jonathan VanAntwerpen, eds. The Power of Religion in the Public Sphere, 118-134. New York: Columbia University Press.

Campbell, Heidi. 2012. "Understanding the Relationship between Religion Online and Offline in a Networked Society." Journal of the American Academy of Religion 80(1):64-93.

Campbell, Heidi and Oren Golan. 2011. "Creating Digital Enclaves: Negotiation of the Internet Among Bounded Religious Communities." Media, Culture, \& Society 33(5):709-724. 
Cohen, Steven and Arnold Eisen. 2000. The Jew Within: Self, Family, and Community in America. Bloomington: Indiana University Press.

Cohen, Steven and Ari Kelman. 2010. "Thinking about Distancing from Israel." Contemporary Jewry 30:287-296.

Coleman, E. Gabriella. 2010. "Ethnographic Approaches to Digital Media." Annual Review of Anthropology 39:487-505.

Eltantawy, Nahed and Julie B. Wiest. 2011. "Social Media in the Egyptian Revolution: Reconsidering Resource Mobilization Theory." International Journal of Communication $5: 1207-1224$.

Engelke, Matthew. 2012. "Angels in Swindon: Public Religion and Ambient Faith in England." American Ethnologist 39(1):155-170.

Fader, Ayala. 2009. Mitzvah Girls: Bringing Up the Next Generation of Hasidic Jews in Brooklyn. Princeton: Princeton University Press. 2012. "Is the Internet the Problem? Sexual Abuse Scandals and Ultra-

Orthodox Jews in Brooklyn." The Revealer: A Daily Review of Religion and Media, November 13. Accessed from http:// therevealer.org/archives/14351 on Feb 3, 2015. 2013. "The Crisis of Faith and the Morality of Media: Nonliberal Jewish

Inspirational Lectures

in Brooklyn." American Anthropologist 115(1):72-84. 2014. "The Multilingual Jewish-Blogosphere." The Immanent Frame:

Secularism, Religion, and the Public Sphere, September 16. Accessed from http://blogs.ssrc.org/tif/2014/09/16/the-multi-lingual-jewish-blogosphere/ on Feb 3, 2015.

Ginsburg, Faye. 1994. "Culture/Media: A (Mild) Polemic." Anthropology Today 10(2):5-15. Ginsburg, Faye, Lila Abu-Lughod, and Brian Larkin, eds. 2002. Media Worlds: Anthropology 
on New Terrain. Berkeley: University of California Press.

Gottlieb, Owen. 2013a. "You Can't Wrap Herring in an iPad: Digitization of Sacred Jewish Books, the Stripping of Embodied Ritual, and Implications for Jewish Education." The Reform Jewish Quarterly. Accessed from httpj7www.bjpa.org/Publications/details.cfm?PublicationlD=16372 on May 29, 2015. 2013b. "Media Studies Orientations for Israel Education: Lessons from In

Treatment,

Homeland, and Z-Cars." Journal of Jewish Education 79(1):49-69.

2015. "Jewish Games for Learning: Renewing Heritage Traditions in the Digital Age." In Heidi Campbell, ed. Digital Judaism: Jewish Negotiations with Digital Media and Culture, 91 -109. London: Routledge.

Graeber, David. 2011. "Interview with Kevin Depew. Occupy Wall Street: On Why the Movement Matters." Minyanville, November 3. Accessed from http://www.minyanville.com/businessmarkets/articles/occu-py-wall-street-demandshow-occupy/11/3/2011/id/37707?page=full on May 25, 2015. . 2013. The Democracy Project: A History, a Crisis, a Movement. New York: Penguin Books.

Habermas, Jurgen. 1989. The Structural Transformation of the Public Sphere: An Inquiry Into a Category of Bourgeois Society. Thomas Berger, trans. Cambridge: MIT Press. 2011. '"The Political': The Rational Meaning of a Questionable Inheritance of Political Theology." In Eduardo Mendieta and Jonathan VanAntwerpen, eds. The Power of Religion in the Public Sphere, 15-33. New York: Columbia University Press.

Heschel, Abraham J. 1962. The Prophets. New York: Harper \& Row.

Hirschkind, Charles. 2006. The Ethical Soundscape: Cassette Sermons And Islamic

Counterpublics. New York: Columbia University Press. 
Hirschkind, Charles and Brian Larkin. 2008. "Introduction: Media and the Political Forms of Religion." Social Text 26(3):1-9.

Hoffman, Michael and Amaney Jamal. 2014. "Religion in the Arab Spring: Between Two Competing Narratives." The Journal of Politics 76(3):593-606.

Hoover, Steven and Nabil Echchaibi. 2012. "Finding Religion in the Media: Work in Progress on the Third Spaces of Digital Rebellion." Working Paper, Center for Media, Religion, and Culture. Boulder: University of Colorado.

Ito, Mizuko, Sonja Baumer, Matteo Bittanti, Danah Boyd, Rachel Cody, Becky HerrStephenson, Heather A. Horst, Patricia G. Lange, Dilan Mahendran, Katynka Z. Martinez, C. J. Pascoe, Dan Perkel, Laura Robinson, Christo Sims, and Lisa Tripp. 2009. Hanging Out, Messing Around, and Geeking Out: Kids Living and Learning with New Media. Cambridge: MIT Press.

Juris, Jeffrey S. 2008. Networking Futures: The Movements Against Corporate Globalization. Durham: Duke University Press. 2012. "Reflections on \#Occupy Everywhere: Social Media, Public Space, and Emerging Logics of Aggregation." American Ethnologist 39(2):259-279. . 2013. "The 99\% and the Production of Insurgent Subjectivity." Cultural Anthropology Online, February 14. Accessed from http://www.culanth.org/fieldsites/72-the-99-and-the-production-of-in-surgentsubjectivity on May 25, 2015.

Kelner, Shaul. 2008. "Ritualized Protest and Redemptive Politics: Cultural Consequences of the American Mobilization to Free Soviet Jewry." Jewish Social Studies: History, Culture, Society 14(3):1 -37. 2010. Tours that Bind: Diaspora, Pilgrimage, and Israeli Birthright Tourism. New York: New York University Press. 
Lievrouw, Leah. 2011. Alternative and Activist New Media. New York: Polity.

Lorber, Ben. 2011. "Flotilla Controversy Within Occupy Wall Street Shows Palestine

Continues to be a Fault Line." Mondoweiss: The War of Ideas in the Middle East,

November 4. Accessed from http:// mondoweiss.net/2011/11/flotilla-controversy-

within-occupy-wall-street-shows-palestine-continues-to-be-a-fault-line.html on July 3, 2014.

Magid, Shaul. 2006. "Jewish Renewal and the Holocaust: A Theological Response." Tikkun 21 (2):59-68.

Mattoni, Alice. 2013. "Beyond Celebration: Toward a More Nuanced Assessment of Facebook in Occupy Wall Street." Cultural Anthropology Online, February 14. Accessed from http://www.culanth.org/ fieldsites/84-beyond-celebration-toward-a-more-nuancedassessment-of-facebook-s-role-in-occu-py-wall-street on May 25, 2015.

Mendieta, Eduardo and Jonathan VanAntwerpen, eds. 2011. The Power of Religion in the Public Sphere. New York: Columbia University Press.

Meyer, Birgit. 2004. "'Praise the Lord': Popular Cinema and Pentacostalite Style in Ghana's New Public Sphere." American Ethnologist 31(1):91 -110. , ed. 2009. Aesthetic Formations: Media, Religion, and the Senses. New York:

Palgrave Macmillan.

Meyer, Birgit and Annelies Moors, eds. 2006. Religion, Media, and the Public Sphere. Bloomington: Indiana University Press.

Murane, Ben. 2011. "'Occupy Yom Kippur' in New York City." Jewschool. Accessed from http://jewschool. com/2011/10/27091/occupy-yom-kippur-in-new-york-city/ on May 26, 2015.

Nugent, David. 2012. "Commentary: Democracy, Temporalities of Capitalism, and Dilemmas of Inclusion in Occupy Movements." American Ethnologist 39(2):280-283. 
Papacharissi, Zizi. 2002. "The Virtual Sphere: The Internet as a Public Sphere." New Media \& Society 9(4):1-24.

Postill, John. 2013. "Participatory Media Research and Spain's 15M Movement." Cultural Anthropology Online, February 14. Accessed from http://culanth.org/fieldsights/86participatory-media-research-and-spain-s-15m-movement on May 29, 2015.

Prell, Riv-Ellen. 1989. Prayer and Community: The Havurah in American Judaism. Indiana: Wayne State University Press. 2000. "Communities of Choice and Memory: Conservative Synagogues in the Late 20th Century." In Jack Wertheimer, ed. Jews in the Center, 269-358. New Brunswick: Rutgers University Press.

Razsa, Maple and Andrej Kurnik. 2012. "The Occupy Movement in Zizek's Hometown: Direct Democracy and a Politics of Becoming." American Ethnologist 39(2):238-258.

Sasson, Theodore. 2013. The New American Zionism. New York: New York University Press.

Schmidt, Leigh Eric. 2002. Hearing Things: Religion, Illusion, and the American Enlightenment. Cambridge: Harvard University Press.

Schneider, Nathan. 2011. "From Occupy Wall Street to Occupy Everywhere." The Nation, October 31. Accessed from http://www.thenation.com/article/163924/occupy-wallstreet-everywhere on July 2, 2014.

Shandler, Jeffrey. 2009. Jews, God, and Videotape: Religion and Media in America. New York: New York University Press.

Solomon, Alissa. 2013. Wonder of Wonders: A Cultural History of Fiddler on the Roof. New York: Metropolitan Press.

Sreberny, Annabelle and Gholam Khiabany. 2010. Blogistan: The Internet and Politics in Iran. London: I. B. Tauris.

Staub, Michael E. 2004. Tom at the Roots. New York: Columbia University Press. 
Stolow, Jeremy. 2010. Orthodox by Design: Judaism, Print Politics, and the Artscroll Revolution. Berkeley: University of California Press.

Taylor, Charles. 2007. A Secular Age. Cambridge: Harvard University Press.

Taylor, Diana. 2003. The Archive and the Repertoire: Performing Cultural Memory in the Americas. Durham: Duke University Press Books. . 2010. "SAVE AS...Memory and the Archive in the Age of Digital Technologies." Presentation at the Forum on the Humanities and the Public World, Berkeley Art Museum Theater, September 30. Accessed from http://www.youtube.com/watch?v=xGurF1RfjOU on Feb 3, 2015.

Wagner, Rachel. 2011. Godwired: Religion, Ritual and Virtual Reality. New York: Routledge. Weissler, Chava. 2006. "'Women of Vision' in the Jewish Renewal Movement: The Eshet Hazon ['Woman of Vision'] Ceremony." Jewish Culture and History 8(3):62-86. 